Article

\title{
Assessment of Risk and Social Impact on Groundwater Pollution by Nitrates. Implementation in the Gallocanta Groundwater Body (NE Spain)
}

\author{
José María Orellana-Macías ${ }^{1, *(\mathbb{D})}$ and María Jesús Perles Roselló ${ }^{2}$ \\ 1 Departamento de Investigación en Recursos Geológicos, Centro Nacional Instituto Geológico y Minero de \\ España, 50006 Zaragoza, Spain \\ 2 Departamento de Geografía, Universidad de Málaga, 29010 Málaga, Spain; mjperles@uma.es \\ * Correspondence: orellana.jmaria@gmail.com
}

check for

updates

Citation: Orellana-Macías, J.M.;

Perles Roselló, M.J. Assessment of Risk and Social Impact on

Groundwater Pollution by Nitrates. Implementation in the Gallocanta

Groundwater Body (NE Spain).

Water 2022, 14, 202. https://doi.org/

$10.3390 / \mathrm{w} 14020202$

Academic Editor: Ashwani

Kumar Tiwari

Received: 3 December 2021

Accepted: 31 December 2021

Published: 11 January 2022

Publisher's Note: MDPI stays neutral with regard to jurisdictional claims in published maps and institutional affiliations.

Copyright: (c) 2022 by the authors. Licensee MDPI, Basel, Switzerland. This article is an open access article distributed under the terms and conditions of the Creative Commons Attribution (CC BY) license (https:/ / creativecommons.org/licenses/by/ $4.0 /)$.

\begin{abstract}
Groundwater is an essential resource for humans concerning freshwater supply; therefore, preserving and protecting its quality is necessary. Risk assessment, based on hazard, intrinsic vulnerability information and mapping, may be considered as a key aspect of sustainable groundwater management. An approach has been made by combining the Nitrogen Input Hazard Index and the hydrogeological parameters considered in a modified DRASTIC method. A three-level classification has been used to determine the degree of risk, and the thresholds have been established following measurable criteria related to the potential nitrate concentration in groundwater. The second part of the study focused on estimating the socioeconomic impact of groundwater pollution by relating the degree of risk and social vulnerability to groundwater pollution. The method has been tested in the Gallocanta Groundwater Body (Spain). As a result, a risk map and an impact map are provided. The risk map shows that $67 \%$ of the study area can be classified as moderate and high-risk areas, corresponding to high hazard sources located in moderate and high vulnerability zones, whereas the impact of groundwater pollution is classified as moderate in the whole groundwater body. The proposed analysis allows comparison between aquifers in different areas and the results required by water authorities to implement control and mitigation measures.
\end{abstract}

Keywords: groundwater contamination; risk assessment; pollution sources; intrinsic vulnerability; Gallocanta

\section{Introduction}

In environmental hazards, risk is defined as the result of the interaction of a hazard, and the vulnerability of the system or element exposed, including the probability of the occurrence of the hazard phenomena [1]. Risk is inherent to the environment, and it may be caused by both natural and anthropogenic factors.

Given human dependence on certain resources, people protection and security lead to the implementation of risk assessments, which comprehend the nature of the risk and determine its level [2]. Risk is assessed by analyzing hazard factors and the vulnerability of the elements potentially at risk, including people, assets, properties and infrastructures, and it provides the basis for implementing measures in order to ensure groundwater protection [3].

Groundwater deterioration has been reported in recent decades in Europe [4,5], America [6], Asia [7,8] and Africa [9]. Urban growth, the spread of agricultural areas and the rising world population have constantly been increasing pressure regarding water resources; therefore, water deterioration is one of the consequences of groundwater overdraft and pollutant emission. The decreasing quality status of freshwater caused by pollutants involves potential health risks to people. Many researchers and public reports have assessed the potential human health risk of several groundwater pollutants in order to establish 
legal thresholds and contribute to the safeguarding of human health [8,10-12]. In the European Union, many countries have reported nitrate groundwater pollution, Spain being the third country with the highest proportion of groundwater monitoring stations with concentrations above $50 \mathrm{mg} \mathrm{L}^{-1}$ (Table 1).

Table 1. Proportion of groundwater monitoring stations with concentrations above $50 \mathrm{mg} \mathrm{L}^{-1}$ in some countries of the European Union during the reporting period 2012-2015 and 2016-2019. Source: Joint Research Centre of European Commission.

\begin{tabular}{cc}
\hline Country & Proportion of Monitoring Stations above $\mathbf{5 0 ~} \mathbf{m g} \mathbf{L}^{-\mathbf{1}} \mathbf{( \% )}$ \\
\hline Belgium & 17 \\
Cyprus & 15 \\
Denmark & 13 \\
France & 13 \\
Germany & 25 \\
Italy & 9 \\
Malta & 66 \\
Netherlands & 10 \\
Portugal & 16 \\
Romania & 11 \\
Spain & 20 \\
Slovakia & 10 \\
Sweden & 1 \\
\hline
\end{tabular}

Since groundwater is one of the most valuable sources of freshwater, groundwater risk assessment has been widely implemented across the world [13-15]. Usually, risk assessments focus on determining groundwater risk to pollution, given groundwater quality can be seriously compromised by contamination and, thus, the use of groundwater for agricultural, urban and drinking purposes may be in danger. The most common approach for risk assessment follows the source-pathway-target model [14,16-18], in which the potential source of pollution (hazard), the flow path of a potential contaminant through the system and the affected area (target) are independently analyzed. However, each kind of potential pollutant has different characteristics, which have to be taken into account in order to correctly estimate the travel time, the concentration of pollutant or the duration of contamination [19]. In this regard, several authors have focused on assessing the risk to certain pollutants, such as nitrates $[18,20]$ or industrial products [21].

In groundwater risk assessment, a hazard is a component that must be analyzed, and it may be defined as a phenomenon, process or activity that may be harmful and damaging to society and the environment [22]. Several authors have developed hazard indexes to evaluate and classify potential sources of pollution, such as the Hazard Index [23], the DCI [24] or the POSH method [25], which can be used as the first step in a groundwater risk assessment to pollution. Most of the studies assessing groundwater risk to pollution use intrinsic vulnerability, which considers physical and natural characteristics of the area. The assessment is performed using an internationally recognized method, such as DRASTIC, GOD, COP, EPIK or LU-IV, and the results allow us to infer the risk of pollution. However, intrinsic vulnerability per se does not allow us to infer risk, since intrinsic vulnerability defines the susceptibility of the aquifer to be polluted, but it does not provide information regarding hazard nor the potential impact of a pollution event on people and economic activities. In this regard, social vulnerability or vulnerability of the human environment [26] focuses on the social aspects of risk [27]. Social vulnerability takes into account economic and social characteristics of the population, so the potential impact of a pollution event can be better estimated. Thus, by including both intrinsic and social vulnerability in the risk assessment, the risk of pollution of the area and the potential impact on the population may be obtained, which improves the accuracy of the results.

Risk assessment may be carried out in pristine zones, areas already polluted, or at risk of pollution, therefore, aiding in the decision-making process to protect and mitigate the effects of pollution. In order to prioritize the areas where control and mitigation measures 
are needed, it is necessary to take into account all the risk elements in an integrated way, i.e., the hazard that endangers groundwater, the intrinsic vulnerability of the aquifer, and the social vulnerability of the people who are dependent of groundwater.

Following the Nitrate Directive (91/676/EEC), the Gallocanta Groundwater Body was declared as a Nitrate Vulnerable Zone in 1997 [28] due to its high nitrate concentration. For the last 25 years, several changes in the protected area have been made, but only slight improvements in groundwater quality have been observed [29]. Agricultural activities are the main source of nitrate in the area, and concentrations are still high in large parts of the aquifer system. In this regard, previous works have already delimited and classified potential sources of pollution [30], mapped the hazard of nitrate pollution [31] and assessed social vulnerability to groundwater pollution [32].

In this context, the ultimate objective of this study is assessing the risk of groundwater pollution of nitrates in the Gallocanta Groundwater Basin by complementing hazard analysis, intrinsic vulnerability and social vulnerability. The second objective aims at estimating the social impact of groundwater pollution in the study area by applying a method that may be replicated in other areas, enabling comparison among aquifers.

\section{Materials and Methods}

\subsection{Study Area}

The Gallocanta Groundwater Body covers approximately $223 \mathrm{~km}^{2}$. It is located in the northeastern part of the Iberian Peninsula (Figure 1) and is associated with the groundwater watershed of the Gallocanta Basin $\left(540 \mathrm{~km}^{2}\right)$, which is an endorheic basin with the Gallocanta Lake in the lowest part.

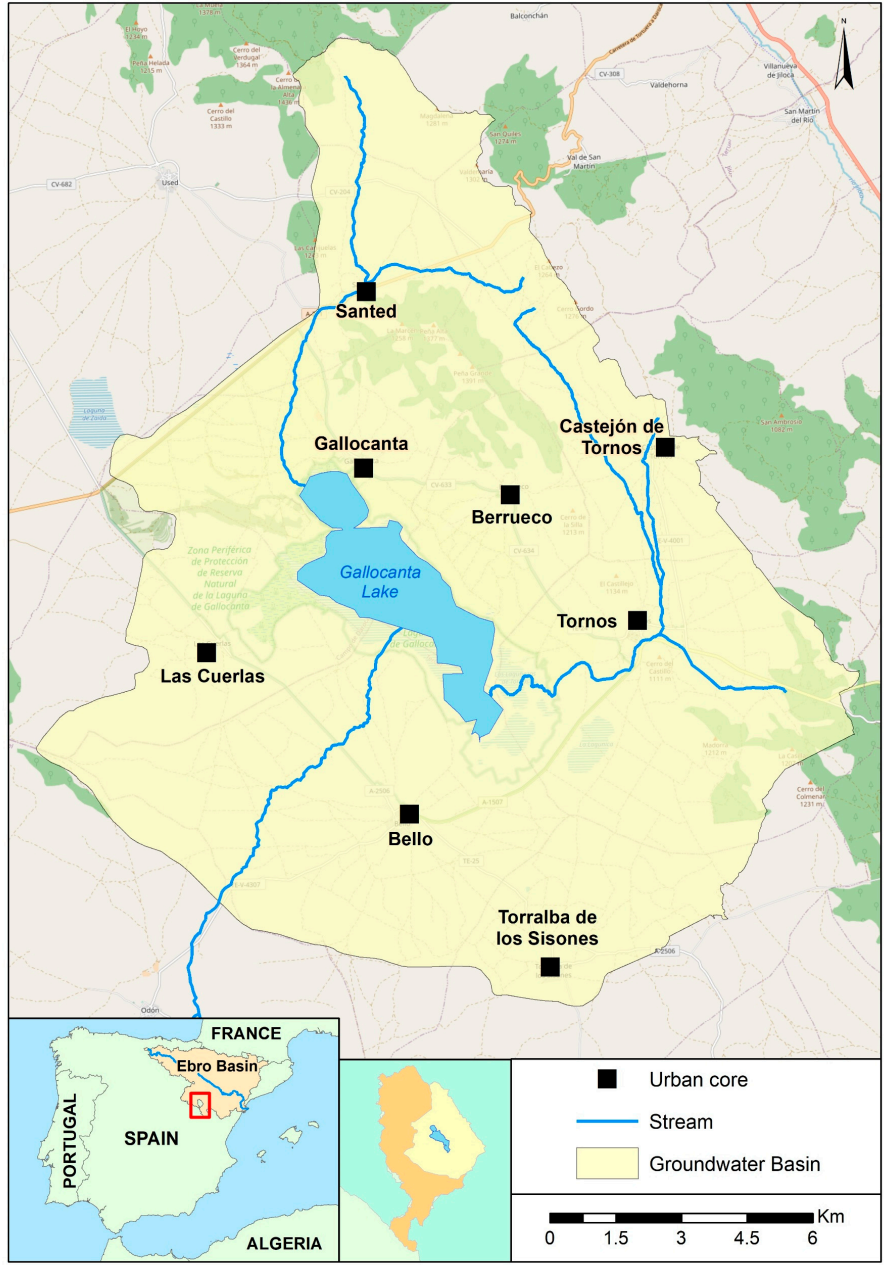

Figure 1. Study area. 
The Gallocanta Groundwater Body is a complex multilayer aquifer system [33]. The uppermost part is a shallow detritic Quaternary aquifer covering low lands and the bottom of the basin. This aquifer is directly connected to the carbonated Cretaceous and Jurassic aquifers that occupy the western half of the basin and the carbonated Triassic aquifer to the East (Figure 2). Those carbonated aquifers outcrop along the western and central part of the basin, whereas most of the eastern sector of the study area is formed by Paleozoic rocks with low permeability, where the main gullies of the area (Royo Creek and Acequia Madre Creek) flow to the lake. Beneath those aquifers, Triassic impervious rocks (mainly Keuper Facies) cover large areas of the study area, allowing the presence of the lake by hindering vertical water fluxes, and partially outcrop in some locations along with the western sector of the study area, which complicates the groundwater flow among the carbonated and the detritic aquifer. Overall, the carbonated aquifers flow into the detritic aquifer, which is directly connected to the lake. Given their accessibility, size and hydraulic characteristics, the Quaternary and the Mesozoic aquifers (Cretaceous and Jurassic) are the most relevant sources of fresh water in the area, making them the object of study of the present research. Further details of the hydrogeological characteristics of the area were analyzed in previous studies $[29,33]$.

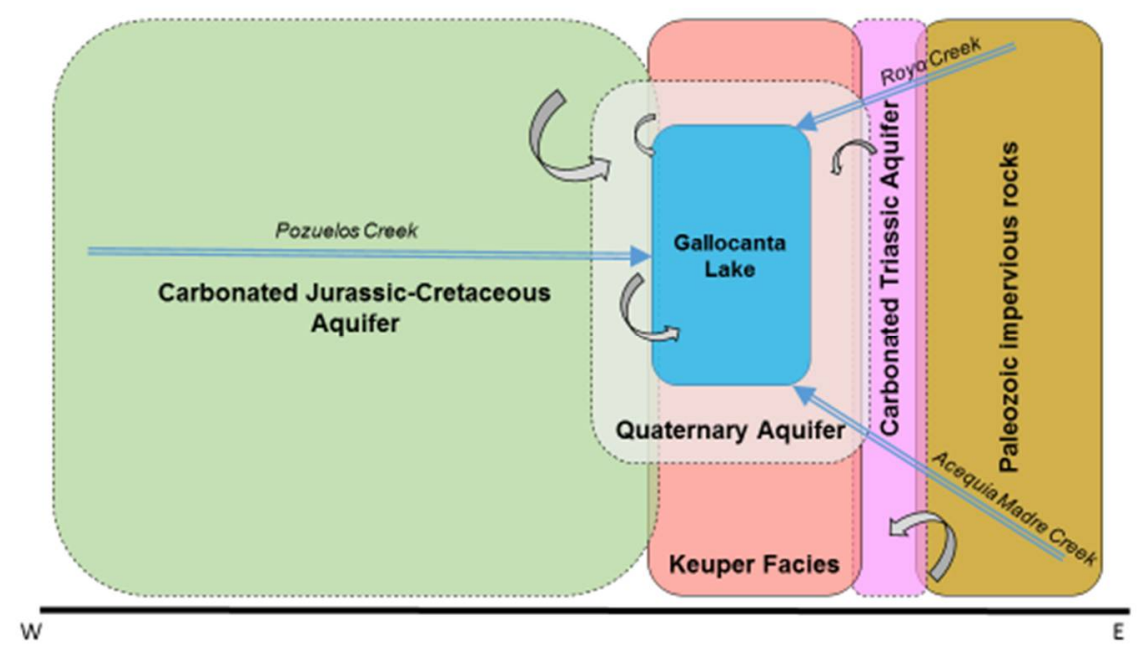

Figure 2. Hydrogeological conceptual model at the Gallocanta Basin.

The area has widely been devoted to intense agricultural activities for decades. According to the CORINE Land Cover, in 2019, $80 \%$ of the area were arable lands, being rainfed agriculture the main agricultural land use $(78 \%)$, whereas $2 \%$ of the territory was irrigated and $20 \%$ were pastured. The main crops were winter cereals (e.g., wheat and barley), sunflower and fodder crops (alfalfa and sainfoin). In this context, following the Nitrate Directive, the groundwater body was declared as a Nitrate Vulnerable Zone in 1997 due to the high nitrate concentration from agricultural sources observed in most of the basin.

\subsection{Methods}

The present approach focuses on the risk and impact of nitrate pollution from agricultural activities on groundwater quality by a three-step risk assessment (Figure 3). The first stage combines hazard mapping and intrinsic groundwater vulnerability, which results in mapping risk to pollution (Step 1). In the first stage, the final output is a risk map that shows the sectors of the aquifer where the risk of pollution is higher, based on the intrinsic vulnerability and the amount of pollutant supplied. 


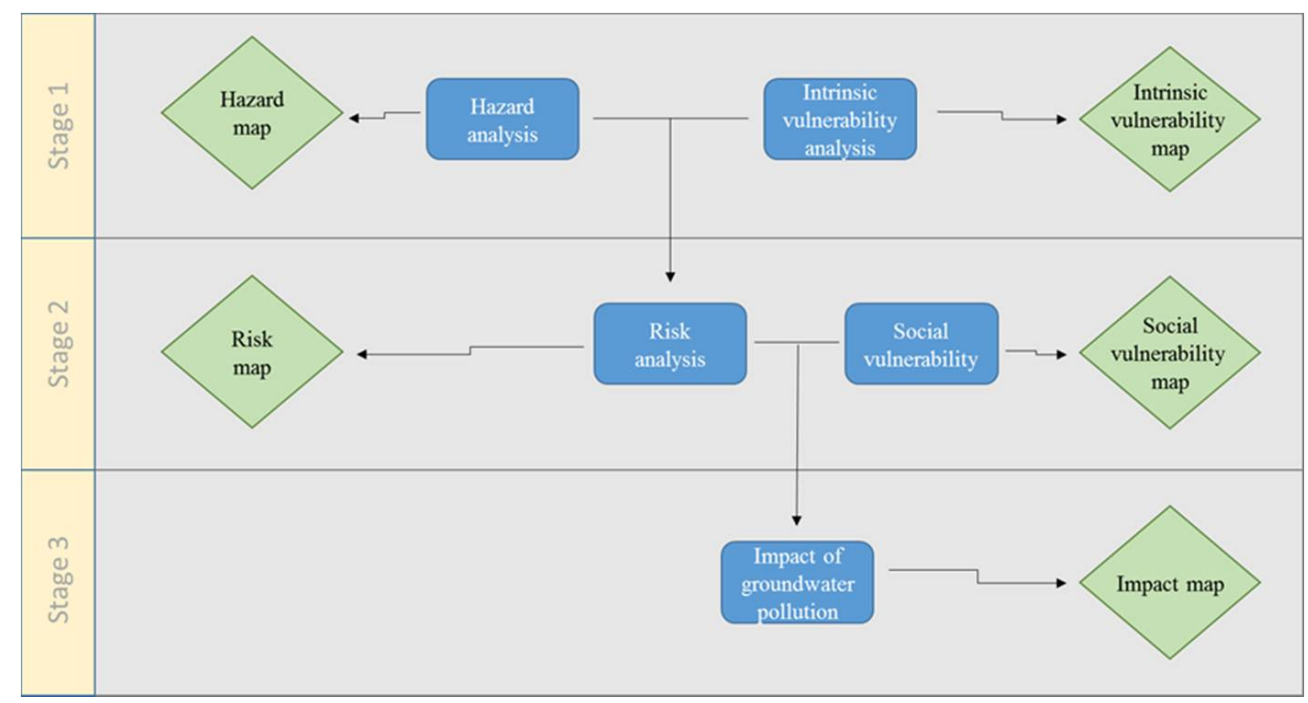

Figure 3. Flow chart of the procedure.

Step 2 includes social vulnerability assessment, this is, an estimation of the human dependency on groundwater, since this would determine the magnitude of a potential groundwater pollution event. A similar pollution event in aquifers with the same risk level may produce different socioeconomic impacts, according to the human dependency on groundwater.

Step 3 is the final stage of the methodology. The risk level estimated in Step 1 is related to social vulnerability obtained in Step 2 in order to assess the final impact of a potential groundwater pollution event. Therefore, the risk level is the result of hazard level, intrinsic vulnerability to pollution and the socioeconomic impact of pollution.

\subsubsection{Step 1. Risk Assessment}

The first stage of the analysis involves the location and classification of hazard sources; this is, a hazard assessment of the nitrate sources. In order to assess and locate the potential sources of nitrate in the study area (mainly crops), the main pollutant activities have been addressed and quantified following the Nitrogen Input Hazard Index (NIHI) [31].

NIHI aims to calculate the total amount of input nitrogen in the study area according to the crops nitrogen fertilizer requirements. Based on the nitrogen fertilizer requirements of each crop, the rating considers the potential amount of nitrogen that could be released from each source and the subsequent nitrate concentration in the aquifer. Thus, this method explores the correlation between nitrogen supply and nitrate concentration in the aquifer.

The index establishes a three-tiered classification. All the crops in the study area are classified as high, moderate or low, depending on the potential amount of nitrogen they require and the estimated amount of nitrogen needed to reach legal thresholds. Those legal thresholds are established by the Nitrate Directive (91/676/CEE). Hazard is low when the calculated nitrogen fertilizer requirement is lower than the nitrogen requirement estimated to reach $25 \mathrm{mg} \mathrm{L}^{-1}$; hazard is moderate when the calculated nitrogen fertilizer requirement is lower than the nitrogen fertilizer requirement estimated to reach $50 \mathrm{mg} \mathrm{L}^{-1}$; and hazard is high when the calculated nitrogen fertilizer requirement is higher than the nitrogen fertilizer estimated to exceed $50 \mathrm{mg} \mathrm{L}^{-1}$ (Table 2).

Table 2. Hazard classification.

\begin{tabular}{cc}
\hline Hazard $\left[\mathrm{NO}_{3}-\right.$ Concentration in $\left.\mathrm{g} \mathrm{L}^{-1}\right]$ & Hazard Level \\
\hline$<25$ & Low \\
$25-50$ & Moderate \\
$>50$ & High \\
\hline
\end{tabular}


The second part of this step evaluates intrinsic vulnerability. Intrinsic vulnerability is based on a reduced version of DRASTIC [34], which is one of the most common indexes to assess intrinsic vulnerability. This version aims to improve the accuracy of the vulnerability assessment by reducing the number of factors used by DRASTIC since some of them may be redundant [35]. The reduced version of DRASTIC is a dimensionless index that uses soil media (S), impact of vadose zone (L), depth to water (E) and net recharge (R). Each parameter is weighted and rated between 1 and 10 (net recharge is rated between 1 and 9), and the final value is between 16 and 156. Intrinsic vulnerability is calculated following Equation (1).

$$
\text { Intrinsic Vulnerability }=3 \mathrm{~S}+4 \mathrm{~L}+5 \mathrm{E}+4 \mathrm{R},
$$

This method was implemented by the Spanish Geological Survey in some large basins in Spain, such as Duero and Guadalquivir [36], and it was later used in other areas, such as the Ebro Basin [37], in which the Gallocanta Basin is included.

Once intrinsic vulnerability has been calculated for the whole study area, it is classified into three levels. Scores between 16 and 58 are considered to be low vulnerability, scores between 58 and 110 are considered as moderate vulnerability, and finally, areas whose score is higher than 110 are included as high vulnerability (Table 3).

Table 3. Vulnerability classification.

\begin{tabular}{cc}
\hline Vulnerability & Vulnerability Level \\
\hline $16-58$ & Low \\
$58-110$ & Moderate \\
$110-156$ & High \\
\hline
\end{tabular}

Once hazard and vulnerability have been evaluated and mapped, the risk assessment is carried out. The risk of pollution is the result of the combination of the intrinsic characteristics of the aquifer (vulnerability), which can be considered relatively static, and the presence of potentially polluting activities (hazard), which are dynamic and easier to control. Thus, the risk level can change based on changes in either vulnerability or hazard. The risk map displays the risk level $(\mathrm{R})$, which is dimensionless, and calculated by multiplying the value of the hazard index $(\mathrm{H})$ and the intrinsic vulnerability (V), as described in Equation (2), based on the General Equation of Risk [38].

$$
\mathrm{R}=\mathrm{H} \times \mathrm{V},
$$

Based on hazard and vulnerability level (Table 4), a matrix is used to classify nine risk levels, from very low, to very high risk, which are subsequently divided into three intervals with the aim of easing map readability.

Table 4. Risk classification.

\begin{tabular}{ccccc}
\hline Hazard & Vulnerability & $\begin{array}{c}\text { Low } \\
\text { Vulnerability }\end{array}$ & $\begin{array}{c}\text { Moderate } \\
\text { Vulnerability }\end{array}$ & $\begin{array}{c}\text { High } \\
\text { Vulnerability }\end{array}$ \\
\hline \multirow{2}{*}{ Low Hazard } & Low Risk & Low Risk & Moderate Risk \\
& Moderate Hazard & Low Risk & Moderate Risk & High Risk \\
High Hazard & Moderate Risk & High Risk & High Risk \\
\hline
\end{tabular}

The risk map may be complemented with the analysis of nitrate concentration observed in sampling points in order to assess the potential correlation between the risk level and the observed pollution in groundwater.

\subsubsection{Step 2. Social Vulnerability Assessment}

The socioeconomic impact of the negative effects of a pollution event is dependent on the intensity of groundwater use and the degree of dependency on human activities. Social 
vulnerability $(\mathrm{VH})$ involves groundwater accessibility, exploitability and use. The economic value of groundwater considers groundwater extraction of anthropogenic activities such as irrigation and drinking consumptions [18].

The socioeconomic relevance of groundwater, and thus, its potential impact on local people, is assessed by implementing the methodology proposed by Perles et al. (2009) [26]. The authors proposed an approach in which socioeconomic aspects, such as population, the profitability of economic activities and the number of jobs that depend on groundwater, are assessed and quantified. The index distinguished three factors related to socioeconomic vulnerability: exposure and vulnerability of the population $\left(\mathrm{V}_{\mathrm{P}}\right)$, exposure and vulnerability of farming activities $\left(\mathrm{V}_{\mathrm{AG}}\right)$ and exposure and vulnerability of other economic activities $\left(\mathrm{V}_{\mathrm{ST}}\right)$. The sum of these weighted factors is used to calculate social vulnerability, following Equation (3):

$$
\text { Social Vulnerability }=3 \mathrm{~V}_{\mathrm{P}} \times 2 \mathrm{~V}_{\mathrm{AG}}+\mathrm{V}_{\mathrm{ST}},
$$

Social vulnerability assessment has to deal with spatial issues since population or activities affected by groundwater pollution may not be located above the aquifer, which is the common area of analysis in risk assessment. Usually, the boundaries of the aquifer do not fit with administrative limits such as municipalities, therefore, in order to ease mapping and data analysis, the aquifer is considered as the basic unit of analysis. As a result, each aquifer is given a final socioeconomic score, which may range between 0 (very low vulnerability) and 30 (very high vulnerability).

\subsubsection{Step 3. Impact of Risk Pollution}

The impact that a pollution event may produce both in a natural and human environment depends on the risk level of the aquifer and the human dependency on groundwater from it. Therefore, the assessment of the final impact of a pollution event is based on the risk level obtained in Step 1, as well as on social vulnerability obtained in Step 2.

Once risk is calculated, a score is given to each interval according to the risk level, as follows: low risk (1); moderate risk (2); high risk (3). The proportion of land in each level is then calculated, and a weighted sum is used to estimate the level of impact (Equation (4)):

$$
(\mathrm{P} \times \mathrm{LR})+\left(\mathrm{P}^{\prime} \times \mathrm{MR}\right)+\left(\mathrm{P}^{\prime \prime} \times \mathrm{HR}\right),
$$

where, $\mathrm{P}$ is the proportion of land in the aquifer classified as low risk (in \%); LR is low risk, which was previously scored as $1 ; \mathrm{P}^{\prime}$ is the proportion of land in the aquifer classified as moderate risk (in \%); MR is moderate risk, previously scored as 2; $\mathrm{P}^{\prime \prime}$ is the proportion of land in que aquifer classified as high risk (in \%); and HR is high risk, previously scored as 3. The result is a dimensionless parameter that may range between 0 and 300 , and it can be used to compare aquifers.

The final impact is calculated by multiplying the calculated social vulnerability of the aquifer and the risk of pollution, calculated earlier in Step 3. The result is a dimensionless parameter that ranges between 0 and 9000. The value of the final impact is the same for the whole aquifer and is useful to compare aquifers from different areas in order to prioritize measures when managing risk.

\section{Results}

The hazard map shows the result of the NIHI (Figure $4 \mathrm{a})$. In $23 \%\left(51 \mathrm{~km}^{2}\right)$ of the study area, the hazard is low, whereas $4 \%\left(8.5 \mathrm{~km}^{2}\right)$ is moderate. On the contrary, the hazard level is high in $45 \%\left(100 \mathrm{~km}^{2}\right)$ of the basin, which includes most of the agricultural plots. 


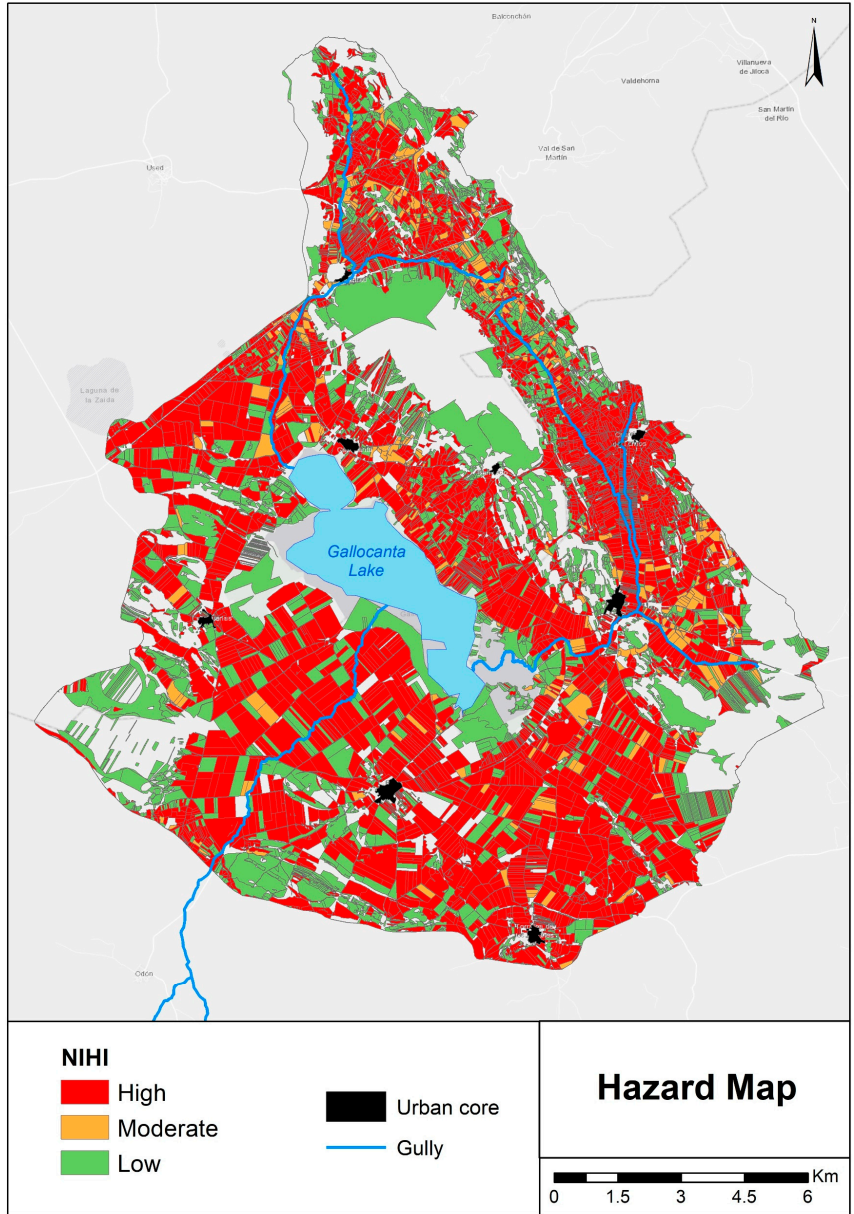

(a)

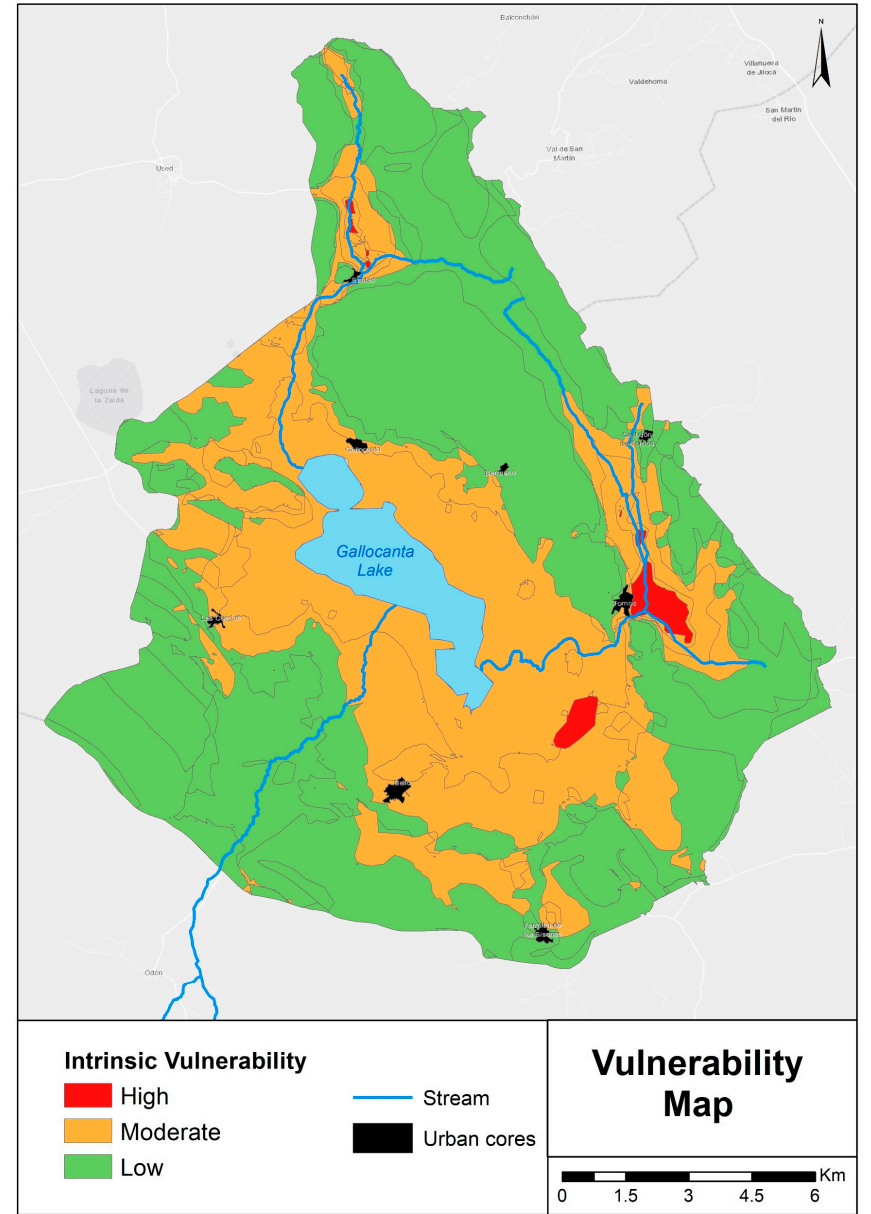

(b)

Figure 4. (a) Hazard map; (b) Intrinsic vulnerability map.

The intrinsic vulnerability map (Figure $4 \mathrm{~b}$ ) displays the result of the modified DRASTIC method. The map shows that vulnerability was low across $57 \%$ of the study area $\left(128 \mathrm{~km}^{2}\right)$, moderate in $37 \%$ of the area $\left(82 \mathrm{~km}^{2}\right)$ and high in only $1 \%$ of the study area $\left(2.3 \mathrm{~km}^{2}\right)$. The highest vulnerability levels are observed in low areas and former lakes, such as La Lagunica, in the southeastern part of the study area. The vulnerability of most of the flat areas surrounding the Gallocanta Lake is classified as moderate, whereas the western part of the territory and the Santa Cruz-Valdelacasa Sierra, in the eastern boundary, is classified as low vulnerability.

In line with the aforementioned risk definition, the risk map reflects the risk level associated with nitrate pollution from agriculture, according to the classification of the pollution sources and the intrinsic characteristics of the area (Figure 5). The map displays low-risk levels across $25 \%$ of the basin $\left(55.4 \mathrm{~km}^{2}\right)$, moderate-risk levels across $24 \%$ of the basin $\left(53.8 \mathrm{~km}^{2}\right)$ and high-risk levels across $22.5 \%$ of the basin $\left(50 \mathrm{~km}^{2}\right)$. The shallow Quaternary aquifer showed worse status, with almost one-third of its area in high risk $(29.5 \%), 17.5 \%$ in moderate risk $\left(22.8 \mathrm{~km}^{2}\right)$ and $16.7 \%$ in low risk. On the other hand, the carbonated aquifer only has $16 \%$ of its area in high-risk, $31 \%$ in moderate-risk and $22 \%$ in low-risk. 


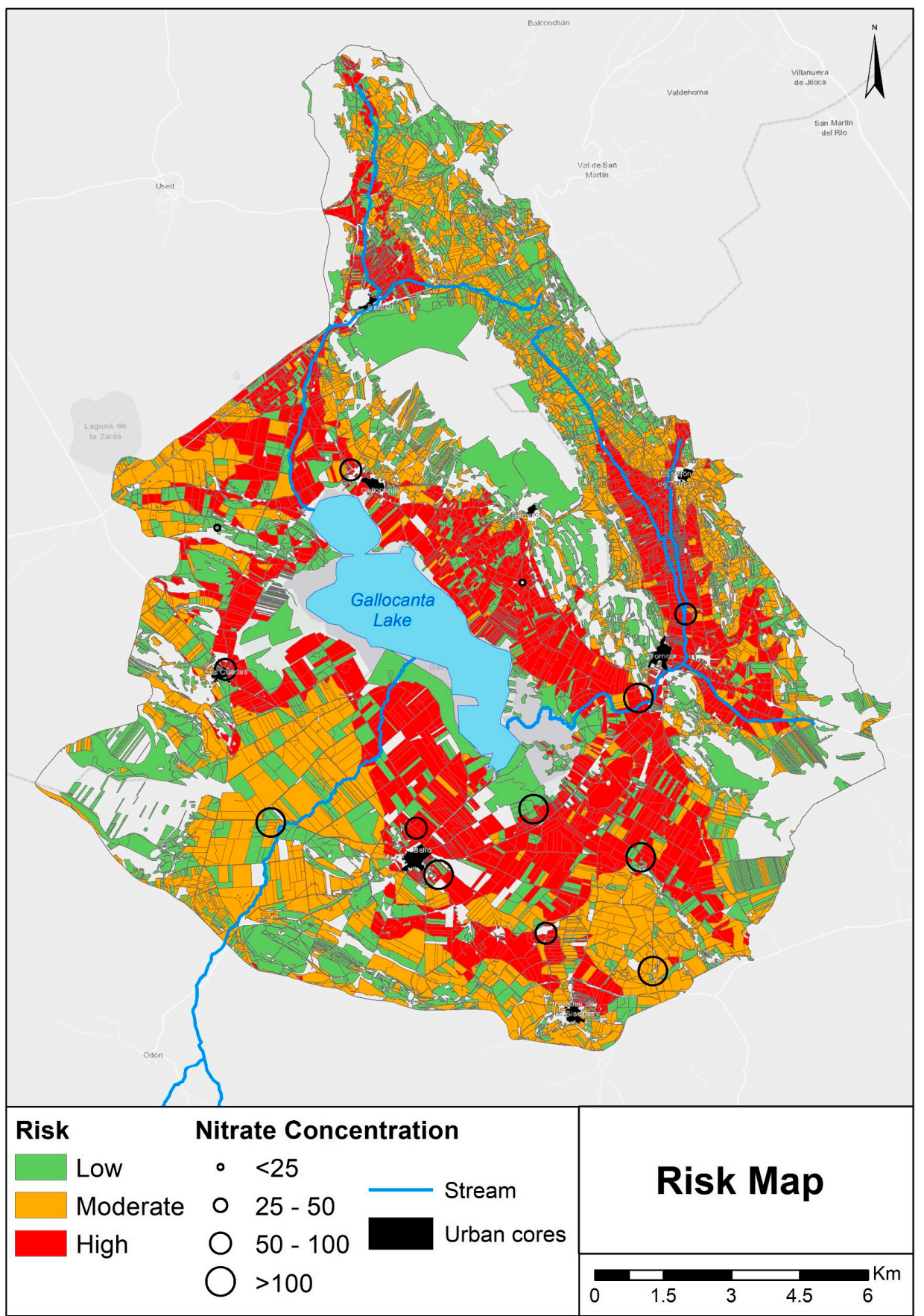

Figure 5. Risk map and nitrate concentration.

In order to explore the spatial relationship between nitrate concentration in sampling points and risk level, a correlation analysis was performed (Figure 5). To do so, 13 sampling points across the study area were used, 6 tapping the Quaternary aquifer and 7 tapping the carbonated aquifer. As a result, 73\% of the sampling points where nitrate concentration was higher than $50 \mathrm{mg} \mathrm{L}^{-1}$ were located in high-risk areas, 18\% in moderate-risk areas and $9 \%$ in low-risk areas, whereas $50 \%$ of the points where nitrate concentration was lower than $25 \mathrm{mg} \mathrm{L}^{-1}$ were located in high-risk areas and 50\% in low-risk areas.

In addition to the specific risk to groundwater nitrate pollution, the potential socioeconomic impact of pollution is assessed. As displayed in Figure 6, the impact of pollution in the aquifers of the study area is Moderate. The score in the shallow Quaternary aquifer is 
slightly higher than in the carbonated Mesozoic aquifer due to the higher proportion of lands at high-risk.

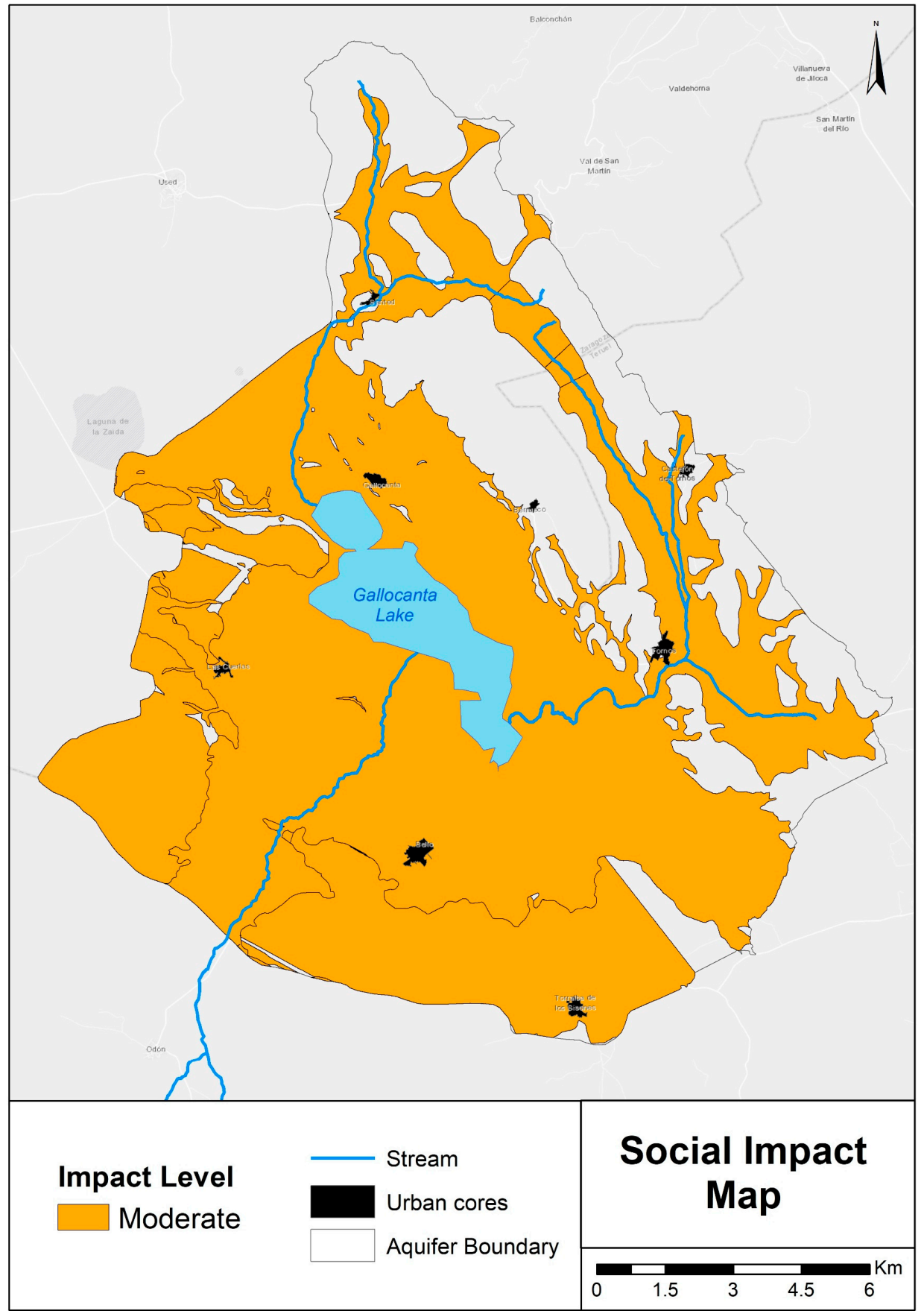

Figure 6. Impact map.

\section{Discussion}

From a methodological point of view, the selected approach allows comparing areas with different characteristics. The selection of internationally recognized methods to calculate hazard, vulnerability and risk, and their combination to estimate impact ease comparison of aquifers. The use of maps that represents the spatial distribution of the categories of hazard, vulnerability, risk and impact has always been a good way to synthesize results and ease spatial comprehension [39]. 
According to the three-step proposed method, two terms must be distinguished: risk and impact. Firstly, risk has been widely studied and defined by many authors $[3,40,41]$, albeit there is no agreed definition of the concept of risk [42]. In this research, risk has been considered as the result of the combination of hazard and intrinsic vulnerability of the system, an approach that is usually adopted in natural hazards and disaster risk reduction research [1]. Secondly, the term impact refers to the socioeconomic elements that can be harmed as a consequence of a groundwater pollution event. This approach involves people and assets exposed to the risk of groundwater pollution, so they can be affected in a polluted scenario. Thus, the combination of both terms allows an integral risk assessment of the area. Potential consequences of a pollution event over people and economic activities have been studied in other areas as Tunisia or Canada [43,44]. In the latter, the authors not only described the potential economic loss but also the healthcare cost of groundwater pollution.

Usually, most of the groundwater pollution risk maps ignore the socioeconomic impact of pollution since they focus on the potential harm of the aquifer and do not consider the negative effects of pollution over human activities dependent on groundwater. In the present study, a methodology to estimate the impact of a potential pollution event is proposed with the aim of improving the integral risk assessment and easing comparison among aquifers.

A common issue when mapping risk to groundwater pollution is that maps are usually complex, and they synthetize several elements. If the classification of hazards, intrinsic vulnerability and social vulnerability includes many intervals or disparate classification criteria, the result tends to show strange spatial analysis units that misrepresent the real situation; therefore, they are not useful to manage the issue at a detailed scale.

In addition, risk assessment usually struggles when quantifying intrinsic and social vulnerability following a dimensional parameter. In this regard, the method aimed to keep the source of information's unit, as well as to use quantitative parameters to represent risk and impact when possible, as it has been carried out in hazard assessment, in order to be able to compare study areas in an objective and representative way. Risk and impact intervals are based on thresholds that are associated with representative changes in the variable behavior and its consequences regarding pollution. The number of intervals remained low with the aim of easing overlapping of information, map readability and keeping the connection between the contribution of each element to the final risk assessment. Therefore, risk and impact intervals avoid random and subjective thresholds that do not represent the real spatial context.

In the study area, most of the high-risk areas are observed in the lowest plots around the Gallocanta Lake, the plain areas at the southern and southwestern sectors of the basin and in the floodplains of the Santed Stream and Tornos Stream, which flow towards the Gallocanta Lake (north and eastern part of the basin). In those areas, hazard tends to be high in most of the plots, whereas vulnerability is moderate due to the lower depth to groundwater and the impact of the vadose zone. On the other hand, low-risk areas are identified in steep areas of the Santa Cruz-Valdelacasa Sierra, where vulnerability is low, and the steep gradient complicates agriculture, in some plots next to the Gallocanta Lake and in other zones devoted to pastures with low vulnerability. Finally, moderate-risk areas are widely observed across the whole study area, usually next to high-risk zones, especially in the hilly southern and southwestern sectors of the basin and in the north boundary of the study area.

Regarding the impact of groundwater pollution, it is classified as moderate in the whole study area. Given the spatial level of detail provided by the socioeconomic vulnerability index, it is not possible to obtain a map with greater spatial detail.

According to Figure 4, the low and moderate social vulnerability of the area (mainly given by its rural nature and the low number of inhabitants) compensates for the high-risk levels observed in most of the study area. In any case, attention must be paid to those 
sectors if changes in land uses are observed since this will probably be associated with a change in the hazard level.

The effectiveness of the risk map may be tested by mapping nitrate concentration in groundwater in 2019. In the study area, the official groundwater quality monitoring network includes 19 sample points. The network is managed by the Hydrographic Ebro Confederation (CHE, from its Spanish Acronym), and data are freely available on the CHE website. These points tap both into the Mesozoic and the Quaternary aquifers and are the basis for declaring Nitrate Vulnerable Zones.

In the Gallocanta Groundwater Body, the nitrate concentration in $85 \%$ of the samples is above $50 \mathrm{mg} \mathrm{L}^{-1}$, the threshold to declare a water body as polluted (91/676 EEC), whereas $15 \%$ of the samples are below $25 \mathrm{mg} \mathrm{L}^{-1}$. Previous studies [31] have already assessed the relationship between nitrate concentration and hazard level in the study area. The authors stated that even in sampling sites where nitrate concentration was lower than $25 \mathrm{mg} \mathrm{L}^{-1}$, the surrounding areas are considered highly hazardous due to the topographic gradient and the influence of regional groundwater flows. However, this can be improved in the risk analysis since intrinsic vulnerability in those areas is estimated to be lower; therefore, the risk map properly represents the risk level of the area surrounding the sampling point. The analysis of the spatial relationship between sampling points and risk level showed that most of the points $(81 \%)$ where nitrate concentration was higher than $50 \mathrm{mg} \mathrm{L}^{-1}$ were indeed located in highrisk areas, whereas the points with nitrate concentration below $50 \mathrm{mg} \mathrm{L}^{-1}$ were located in lowrisk areas and highrisk areas. In these cases, this is explained by intrinsic topographic characteristics and groundwater dynamics, which also explain that nitrate concentration above $100 \mathrm{mg} \mathrm{L}^{-1}$ can be observed in sampling points located in low-risk areas. Nitrate concentration in groundwater has widely been used to validate risk, hazard and vulnerability methods and indexes [45-47] since it is a common and trustful indicator of the groundwater qualitative status. In other study cases, the author found that nitrate concentration in sampling points does not necessarily follow the hazard, vulnerability or spatial risk pattern, so hydrogeological explanations must be found [48]. In our study area, these hydrogeological explanations also complicated the use of pollution in groundwater as an indicator of the effectiveness of the risk map.

In the study area, groundwater flows from the carbonated Mesozoic aquifers to que shallow Quaternary aquifer [33] that occupies the bottom of the basin, the valleys and the area inundated by the Gallocanta paleo-lake [49]. Thus, nitrate removed from upper areas is leached to the surroundings of Gallocanta Lake following the regional and local groundwater flow. Additionally, the endorheic nature of the basin enhances nitrate accumulation in not only the aquifers but also its temporal persistence, as it has been already reported in similar basins [50]. This characteristic allows the persistence of pollution for decades, so natural denitrification processes are essential [46]. Those processes are key when estimating groundwater's intrinsic vulnerability, as already stated by Aschonitis et al. (2014) [51] and Busico et al. (2020) [52].

\section{Conclusions}

When analyzing specific pollutants such as nitrates, risk assessments have to focus on agricultural lands, which are the main sources of this substance. Given the essential role of groundwater as a freshwater supplier and the relevance of agriculture activities in rural areas, the assessment of the socioeconomic impact of pollution provides a better insight into the real context in a certain area. The socioeconomic perspective in pollution risk assessment reaches a special meaning in a climate change scenario, in which the increasing drought risk would likely increase the human dependency on groundwater.

The results in the Gallocanta Groundwater Body showed that risk is moderate to high in most of the area, and the socioeconomic impact was classified as moderate, influenced by the strong dependency on groundwater and the demographic context. This would lead to severe damage to the economy of the region, masked by the size of the affected 
population, which may be reduced by the presence of alternative sources of freshwater that could guarantee the water supply in the case of a recurrent polluted scenario.

The risk and the impact assessment provided in the present research may be used as a tool to manage land uses and agricultural activities through control programmes, reinforce water supply infrastructures and improve groundwater quality. Given that groundwater status in the study area is currently bad, any tool that may help improve it should be implemented and used by technicians, researchers and water authorities.

Author Contributions: Conceptualization, J.M.O.-M. and M.J.P.R.; methodology J.M.O.-M. and M.J.P.R.; software, J.M.O.-M.; formal analysis, J.M.O.-M.; writing—original draft preparation, J.M.O.-M.; writingreview and editing, M.J.P.R.; visualization, J.M.O.-M.; supervision, M.J.P.R. All authors have read and agreed to the published version of the manuscript.

Funding: This research was funded by the Government of Aragon, grant number C137/2016, by the Spanish Ministry of Science and Innovation-FEDER funds [EU] via the Research Project Agro-SOS, grant number PID2019-108057RB-I00.

Data Availability Statement: In this section, please provide details regarding where data supporting reported results can be found, including links to publicly archived datasets analyzed or generated during the study. Data related to types of crops have been provided by the Government of Aragón, previous official request at (https: / / www.aragon.es/- / estadisticas-agrarias, accessed on 30 September 2020). Data about land use were obtained from the Official Spanish Cadastre (http:/ / www.sedecatastro.gob.es/, accessed on 6 October 2020). Data related to groundwater quality were freely available from the Hydrographic Ebro Confederation database (http:/ / www.datossubterraneas.chebro.es:81/WCAS/, accessed on 20 October 2020). Finally, data related to social vulnerability was obtained from the Government of Aragón website (https:/ / www.aragon.es/organismos/departamento-de-economiaplanificacion-y-empleo/direccion-general-de-economia/instituto-aragones-de-estadistica-iaest-, accessed on 3 March 2020).

Acknowledgments: The authors would like to thank the Government of Aragón for providing official data and expert help.

Conflicts of Interest: The authors declare no conflict of interest. The funders had no role in the design of the study, in the collection, analyses, or interpretation of data, in the writing of the manuscript, or in the decision to publish the results.

\section{References}

1. Birkmann, J. Risk. In Encyclopedia of Natural Hazards; Bobrowsky, P.T., Ed.; Springer: Dordrecht, The Netherlands, 2013. [CrossRef]

2. Lacasse, S. Risk Assessment. In Encyclopedia of Natural Hazards; Bobrowsky, P.T., Ed.; Springer: Dordrecht, The Netherlands, 2013. Available online: https:/ /link.springer.com/referenceworkentry/10.1007/978-1-4020-4399-4_297 (accessed on 25 September 2020).

3. Daly, D.; Hötzl, H.; De Ketelaere, D. Risk Assessment. In Vulnerability and Risk Mapping for the Protection of Carbonate (Karst) Aquifers (COST Action 620); Zwahlen, F., Ed.; European Commission, Directorate-General XII Science, Research and Development: Brussels, Belgium, 2004; pp. 106-121.

4. Trabada-Crende, F.; Vinten, A.J.A. Assessing the effects of land management and catchment hydrology on well water quality in a designated nitrate vulnerable zone. Agric. Syst. 1998, 57, 523-540. [CrossRef]

5. Larsen, M.A.D.; Soegaard, H.; Hinsby, K. Temporal trends in N \& P concentrations and loads in relation to anthropogenic effects and discharge in Odense River 1964-2002. Hydrol. Res. 2008, 39, 41-54. [CrossRef]

6. Jurgens, B.C.; Fram, M.S.; Rutledge, J.; Bennett, V.G.L. Identifying areas of degrading and improving groundwater-quality conditions in the State of California, USA, 1974-2014. Environ. Monit. Assess. 2020, 192, 250. [CrossRef]

7. Lapworth, D.J.; Krishan, G.; MacDonald, A.M.; Rao, M.S. Groundwater quality in the alluvial aquifer system of northwest India: New evidence of the extent of anthropogenic and geogenic contamination. Sci. Total Environ. 2017, 599-600, 1433-1444. [CrossRef]

8. Xiao, Y.; Hao, Q.; Zhang, Y.; Zhu, Y.; Yin, S.; Qin, L.; Li, X. Investigating sources, driving forces and potential health risks of nitrate and fluoride in groundwater of a typical alluvial fan plain. Sci. Total Environ. 2022, 802, 149909. [CrossRef]

9. Li, Z.; Wang, G.; Wang, X.; Wan, L.; Shi, Z.; Wanke, H.; Uahengo, C.I. Groundwater quality and associated hydrogeochemical processes in Northwest Namibia. J. Geochem. Explor. 2018, 186, 202-214. [CrossRef]

10. Hao, Q.; Xiao, Y.; Chen, K.; Zhu, Y.; Li, J. Comprehensive understanding of groundwater geochemistry and suitability for sustainable drinking purposes in confined aquifers of the Wuyi region, central north china plain. Water 2020, 12, 3052. [CrossRef] 
11. Xiao, Y.; Liu, K.; Yan, H.; Zhou, B.; Huang, X.; Hao, Q.; Zhang, Y.; Zhang, Y.; Liao, X.; Yin, S. Hydrogeochemical constraints on groundwater resource sustainable development in the arid Golmud alluvial fan plain on Tibetan plateau. Environ. Earth Sci. 2021, 80, 750. [CrossRef]

12. Xiao, Y.; Xiao, D.; Hao, Q.; Liu, K.; Wang, R.; Huang, X.; Zhang, Y. Accessible Phreatic Groundwater Resources in the Central Shijiazhuang of North China Plain: Perspective from the Hydrogeochemical Constraints. Front. Environ. Sci. 2021, 9, 475. [CrossRef]

13. Lytton, L.; Howe, S.; Sage, R.; Greenaway, P. Groundwater abstraction pollution risk assessment. Water Sci. Technol. 2003, 47, 1-7. [CrossRef]

14. Perles, M.J.; Vías, J.M.; Andreo, B. Cartografía de Vulnerabilidad y Riesgo de Contaminación en Acuíferos Carbonatados. In Investigaciones en Sistemas Kársticos Españoles; Andreo, B., Durán, J., Eds.; Instituto Geológico y Minero de España: Madrid, Spain, 2004; pp. 247-275.

15. Wang, J.; He, J.; Chen, H. Assessment of groundwater contamination risk using hazard quantification, a modified DRASTIC model and groundwater value, Beijing Plain, China. Sci. Total Environ. 2012, 432, 216-226. [CrossRef]

16. Zwahlen, F.; Goldscheider, N.; Neale, S. Introduction. In Vulnerability and Risk Mapping for the Protection of Carbonate (Karst) Aquifers; Zwahlen, F., Ed.; Office for Official Publications of the European Communities: Luxembourg, 2004; pp. 1-4.

17. Werz, H.; Hötzl, H. Groundwater risk intensity mapping in semi-arid regions using optical remote sensing data as an additional tool. Hydrogeol. J. 2007, 15, 1031-1049. [CrossRef]

18. Saidi, S.; Bouri, S.; Dhia, H.B.; Anselme, B. Assessment of groundwater risk using intrinsic vulnerability and hazard mapping: Application to Souassi aquifer, Tunisian Sahel. Agric. Water Manag. 2011, 98, 1671-1682. [CrossRef]

19. Stevenazzi, S. Groundwater vulnerability or groundwater pollution risk? Rend. Online Soc. Geol. Ital. 2016, 41, 84-87. [CrossRef]

20. Shrestha, S.; Semkuyu, D.J.; Pandey, V.P. Assessment of groundwater vulnerability and risk to pollution in Kathmandu Valley, Nepal. Sci. Total Environ. 2016, 556, 23-35. [CrossRef]

21. Dimitriou, E.; Karaouzas, I.; Sarantakos, K.; Zacharias, I.; Bogdanos, K.; Diapoulis, A. Groundwater risk assessment at a heavily industrialised catchment and the associated impacts on a peri-urban wetland. J. Environ. Manag. 2008, 88, 526-538. [CrossRef]

22. Nadim, F. Hazard. In Encyclopedia of Natural Hazards; Bobrowsky, P.T., Ed.; Encyclopedia of Earth Sciences Series; Springer: Dordrecht, The Netherlands, 2013.

23. De Ketelaere, D.; Hötzl, H.; Neukum, C.; Civita, M.; Sappa, G. Hazard Analysis and Mapping. In Vulnerability and Risk Mapping for the Protection of Carbonate (Karst) Aquifers (COST Action 620); Zwahlen, F., Ed.; European Commission, Directorate-General XII Science, Research and Development: Brussels, Belgium, 2004; Volume 1, pp. 86-105.

24. Civita, M.V.; De Maio, M. Assessing Groundwater contamination risk using ArcInfo via GRID function. In Proceedings of the ESRI Conference 1997, San Diego, CA, USA, 8-11 July 1997.

25. Foster, S.; Hirata, R.; Gomes, D.; D’Elia, M.; Paris, M. Groundwater Quality Protection; Groundwater Management Advisory Team, Ed.; The World Bank: Washington, DC, USA, 2002.

26. Roselló, M.J.P.; Martinez, J.M.V.; Navarro, B.A. Vulnerability of human environment to risk: Case of groundwater contamination risk. Environ. Int. 2009, 35, 325-335. [CrossRef]

27. di Girasole, E.G.; Cannatella, D. Social vulnerability to natural hazards in urban systems. An application in Santo Domingo (Dominican Republic). Sustainability 2017, 9, 2043. [CrossRef]

28. BOA (1997) DECRETO 77/1997, de 27 de Mayo, del Gobierno de Aragón, por el Que se Aprueba el Código de Buenas Prácticas Agrarias de la Comunidad Autónoma de Aragón y se Designan Determinadas Áreas Zonas Vulnerables a la Contaminación de las Aguas por los Nitratos Procedentes de Fuentes Agrarias [Order 77/1997, 27 May, of the Goverment of Aragón, to Approve the Code of Good Agricultural Practice of the Autonomous Region of Aragón, and the Appointment of Areas as Vulnerable Zones to the Water Pollution of Nitrates from Agricultural Sources]; Government of Aragon: Aragon, Spain, 1997.

29. Orellana-Macías, J.M.; Merchán, D.; Causapé, J. Evolution and assessment of a nitrate vulnerable zone over 20 years: Gallocanta groundwater body (Spain). Hydrogeol. J. 2020, 28, 2207-2221. [CrossRef]

30. Orellana-Macías, J.M.; Roselló, M.J.P. A comparative analysis of methods for mapping groundwater pollution hazard: Application to the Gallocanta Hydrogeologic Unit (Spain). Bol. Asoc. Geógr. Esp. 2020, 85, 1-42. [CrossRef]

31. Orellana-Macías, J.M.; Roselló, M.J.P.; Causapé, J. A Methodology for Assessing Groundwater Pollution Hazard by Nitrates from Agricultural Sources: Application to the Gallocanta Groundwater Basin (Spain). Sustainability 2021, 13, 6321. [CrossRef]

32. Orellana-Macías, J.M.; Roselló, M.J.P. Evaluación cartográfica de la vulnerabilidad del medio humano ante la contaminación de las aguas en la Masa de Agua Subterránea de Gallocanta (Aragón, España). Cuad. Geogr. 2022; in press.

33. San Román, J. Establecimiento de las Normas de Explotación de la Unidad Hidrogeológica "Gallocanta" y Delimitación de los Perímetros de Protección de la Laguna. Zaragoza, Spain. Unpublished work. 2003.

34. Aller, L.; Bennet, T.; Lehr, J.H.; Petty, R.J. DRASTIC. A Standardized System for Evaluating Groundwater Pollution Potential Using Hydrogeologic Settings; U.S. EPA Report 600/2-87-035; U.S. EPA: Tulsa, OK, USA, 1987.

35. Jiménez-Madrid, A.; Martínez, C.; Luque, J.A.; Rubio-Campos, J.C.; Carrasco, F. Estrategias de protección del agua subterránea destinada al consumo humano en la cuenca del Guadalquivir. Bol. Geol. Min. 2013, 124, 3-19.

36. DGOHCA; IGME. Cartografía de Vulnerabilidad de Acuíferos Subterráneos a la Contaminación en la cuenca hidrográfica del Guadalquivir. Unpublished report. 2002. 
37. IGME; DGA. Encomienda de Gestión para la Realización de Trabajos Científico-Técnicos de Apoyo a la Sostenibilidad y Protección de las Aguas Subterráneas; Dirección General del Agua and Instituto Geológico y Minero de España: Madrid, Spain, 2009.

38. Ayala-Carcedo, F.J.; Cantos, J.O. Riesgos Naturales; Ariel: Barcelona, Spain, 2002.

39. Massone, H.E.; Barilari, A. Groundwater pollution: A discussion about vulnerability, hazard and risk assessment. Hydrogeol. J. 2020, 28, 463-466. [CrossRef]

40. Aven, T.; Renn, O. On risk defined as an event where the outcome is uncertain. J. Risk Res. 2009, 12, 1-11. [CrossRef]

41. Ostrom, L.T.; Wilhelmsen, C.A. Risk Assessment Tools, Techniques, and Their Applications; John Wiley \& Sons: Hoboken, NJ, USA, 2012.

42. Aven, T. The risk concept-historical and recent development trends. Reliab. Eng. Syst. Saf. 2012, 99, 33-44. [CrossRef]

43. Saidi, S.; Bouri, S.; Dhia, H.B. Groundwater vulnerability and risk mapping of the hajeb-jelma aquifer (central Tunisia) using a gis-based drastic model. Environ. Earth Sci. 2010, 59, 1579-1588. [CrossRef]

44. Simpson, M.W.M.; Allen, D.M.; Journeay, M.M. Assessing risk to groundwater quality using an integrated risk framework. Environ. Earth Sci. 2014, 71, 4939-4956. [CrossRef]

45. McLay, C.D.A.; Dragten, R.; Sparling, G.; Selvarajah, N. Predicting groundwater nitrate concentrations in a region of mixed agricultural land use: A comparison of three approaches. Environ. Pollut. 2001, 115, 191-204. [CrossRef]

46. Kazakis, N.; Voudouris, K.S. Groundwater vulnerability and pollution risk assessment of porous aquifers to nitrate: Modifying the DRASTIC method using quantitative parameters. J. Hydrol. 2015, 525, 13-25. [CrossRef]

47. Arauzo, M. Vulnerability of groundwater resources to nitrate pollution: A simple and effective procedure for delimiting Nitrate Vulnerable Zones. Sci. Total Environ. 2016, 575, 799-812. [CrossRef]

48. Busico, G.; Kazakis, N.; Colombani, N.; Mastrocicco, M.; Voudouris, K.; Tedesco, D. A modified SINTACS method for groundwater vulnerability and pollution risk assessment in highly anthropized regions based on $\mathrm{NO}_{3}{ }^{-}$and $\mathrm{SO}_{4}{ }^{2-}$ concentrations. Sci. Total Environ. 2017, 609, 1512-1523. [CrossRef]

49. Luzón, A.; Pérez, A.; Mayayo, M.J.; Soria, A.R.; Goñi, M.F.S.; Roc, A.C. Holocene environmental changes in the Gallocanta lacustrine basin, Iberian Range, NE Spain. Holocene 2007, 17, 649-663. [CrossRef]

50. Valiente, N.; Carrey, R.; Otero, N.; Soler, A.; Sanz, D.; Muñoz-Martín, A.; Gómez-Alday, J.J. A multi-isotopic approach to investigate the influence of land use on nitrate removal in a highly saline lake-aquifer system. Sci. Total Environ. 2018, 631-632, 649-659. [CrossRef]

51. Aschonitis, V.G.; Mastrocicco, M.; Colombani, N.; Salemi, E.; Castaldelli, G. Assessment of the intrinsic vulnerability of agricultural land to water and nitrogen losses: Case studies in Italy and Greece. In Proceedings of the International Association of Hydrological Sciences, Bologna, Italy, 14-19 June 2014. [CrossRef]

52. Busico, G.; Kazakis, N.; Colombani, N.; Khosravi, K.; Voudouris, K.; Mastrocicco, M. The importance of incorporating denitrification in the assessment of groundwater vulnerability. Appl. Sci. 2020, 10, 2328. [CrossRef] 